\title{
XINJIANG HUMAN RIGHT VIOLATION AND RADICALISM ISSUES : A DEVELOPMENT INEQUALITY FRAMING
}

\author{
Andi Ismira \\ Lecturer on International Relations Departmen, Universitas Sulawesi Barat \\ Email: andi.ismira@unsulbar.ac.id \\ Ahmad Amiruddin Tennang \\ Lecturer on Political Science Department, Universitas Sulawesi Barat \\ Email: hmadamiruddin@unsulbar.ac.id
}

\begin{abstract}
This Article aiming to discuss about recent Human Right Situation of Uyghur People in Xinjiang Province and the logic of powerful and structural effort by Beijing's Authority to push "De-Extrimification" through "Strike Hard" program. A situation where, non-Chinese societies being forced to conform to Chinese culture, particularly that of the ethnic Han majority. The policies, politically seems like a will to annihilate identity of a society to determine their destiny, and to re-establish themselves in future generations. This writingalso eager to examine, what was the driving factor the radicalism acts which has been occur in Xinjiang since over centuries, that this Radicalis has dragging the Chinese government to put the Policies on stage and seems not going to be downwarded. Using, Descriptive Analityc methods, this article analize the Uyghur and Xinjiang situation with geo-politic, development inequality and human security concepts.
\end{abstract}

Key Word : Xinjiang Human Right Violation, Development Inequality, Geopolitic,

Radicalism

\begin{abstract}
Abstrak
Artikel ini bertujuan untuk membahas tentang Situasi Hak Asasi Manusia Penduduk Uyghur baru-baru ini di Provinsi Xinjiang dan logika upaya kuat dan struktural oleh Otoritas Beijing untuk mendorong "De-Ekstrimifikasi" melalui program "Strike Hard". Situasi di mana, masyarakat non-Cina dipaksa untuk menyesuaikan diri dengan budaya Cina, khususnya yang berasal dari etnis Han. Kebijakan-kebijakan tersebut, secara politis Nampak seperti sebuah usaha untuk menghilangkan identitas masyarakat untuk menentukan nasib mereka, dan untuk membangun kembali diri mereka di generasi mendatang. Tulisan ini juga ingin menguji, apa faktor pendorong tindakan radikalisme yang telah terjadi di Xinjiang sejak berabad-abad lalu hingga kini, Artikel disusun menggunakan, metode analisis deskriptif dengan menggunakan perspektif geo-politik, ketidakadilan pembangunan dan Human Security.
\end{abstract}

Kata Kunci: Pelanggaran HAM Xinjiang, Ketimpangan Pembangunan, Geopolitik, Radikalisme. 


\section{A. Introduction}

In contemporary global political dynamics, these late two decades, China had shows a grand accomplishment of not only economic development, but also attempts to present the world as a global center of new powers, characterized by some principles of foreign policy such as the One Belt One Road (OBOR), as well as its effort to claim the South China Sea. Along with its broaden and massive economic changes and development, human right violence were also prominently recorded. China's attempts to use military power and a series of repressive policies primarily against minority citizens, driven by the China self proclaimed of radical and separatism cleansing motives under the supremacy of communist ideology and policy. The tragedy of the Tibetan people, and the Falun Gong group left the marks of trauma trails of violence in China in the process of Nation-Building shaping.

Xinjiang, one of the largest provinces in China, has been home to millions of Uyghurs belonging to China's authoritative territory since 1949. Half of the 26 million inhabitants in the Region are Muslim. Xinjiang is one of the provinces in China where separatist groups have been in action demanding independence since the end of the 1940s.conflict began to get international attention after the bus bombing incident 2009 in Urumqi, where the separatist group East Turkistan Independence Movement (ETIM) Muslim by the Chinese government was considered as the most responsible party. This riots involving Hans and Uyghurs ethnic in Urumqi, mutually attacking each other bussines center (Clarke,2010).

Ethnic dimension between the Uyghurs and Han embodied a far greater description of ethnic groups tentions opposing the State and all policies implemented in the Xinjiang region. The conflict raised a lot about the resistance of the Uyghurs in Xinjiang under Chinese rule. Since then, studies of the conflict situation in Xinjiang have been increasingly productive. The violence in Urumqi which represented tensions between ethnic Uyghurs and Han, apparently is not the first time exploded. In 1997, Chinese people were shocked by large-scale demonstrations, chaos and bus bombings involving Uyghur insurgents as a form of protest against the Chinese government and demands for independence (Dillon, 1997).

These rebellion warns the government, labelling it as a separatism 
and terrorism in the Xinjiang region, towards the Uyghur community which is furtherly responded with the establishment of controversial "Strike Hard" program In May 2014 (Hughes, 2018). This policy was articulated into a series of strict disciplinary actions against the Uyghur community. There have been many reports both by individuals and humanitarian working group, proclaiming the strong suspicion that, in order to discipline the Uyghur, gradually the Chinese Government established political education camps, and a pretrial detention center.

Both facilities, by the Chinese government, are recognized as centers of training and education for nation character building. An educational process aimed at preventing and eradicating ideological viruses of separatism and radicalism. This article discusses the complexity of the conflict in Xinjiang into 4 Discussion. The first part will trace the background of China's De-Extremization policy towards Xinjiang and other forms of radicalism that legitimize the birth of the "hard beat" policy.

Second part of the article elaborate the discussion of China's geopolitical and geo-economic interests in the Xinjiang region, as a rational factor driving the birth of disciplinary programs in political camps held. In the third part, this article will look at Xinjiang natural resourse abundancseinto the framing Endegenous Economic growth. The fourth section, discussing about the correlation of development inequality in Xinjiang as a main driven factor into radicalism raises related to human security theory.

\section{B. Tracing the China's De- ekstrimization policy and Story of Separatism act in Xinjiang.}

The latest report on Human Rights Watch, in 2018 entitled Eradicating Ideological Virusses, explained that since the Strike Hard policy was implemented, the number of officially captured Uyghurs has tripled compared to 2009. The arresting carried out based on suspicions, although without clear evidence and stages. This formula of "education" entitling by the Xinjiang Chinese Communist Youth League as an "Effective Crime Measures" actions to eradicate thoughts about religious extremism and terrorism, and ideological diseases. It has been multireported, that this form of policies somehow performs the practices of violence indoctrination. 
The official, set the conduction of Data collecting on Uyghurs, without consent. And those who suspected according to the government determination then imprisoned into the "Education" camps to undergo political indoctrination, for undetermined periode (Human Right Watch, 2018).

Although the Chinese government does not provide open information about the number of prisoners in these camps, a credible estimation says that the number of people in these camps is around one million (Zen, 2018).

In 2018, Human Rights Watch interviewed 58 Uyghurs people, reported that half or more members family were prisoned in a pre-trial detainees, without clear legal procedures, rendering the separation between family members in a prominent number (HRW,2018). The Xinjiang authorities also carry out compulsory biometric data collection, such as voice and DNA samples, to identify, create profiles, and tracking everyone in Xinjiang.

CERD investigative findings which was reported at the World Uyghur Congress 2018 forum, outlining some forms of human rights violations which forced the Uyghurs neglected their fundamental rights to actuate their cultural value system. In the name of "deextremification", some policies on "Deextremification" which seen by how it goes, perceively targetted the moslem community in Xinjiang (CERD, 2018).

The policies set these package of prohibition as association, into "extremification". Those are: Wearing clothing with face coverings; growing "irregular beards"; bearing symbols of "extremification"; publishing or possessing information with "extremist content". The parents also prohibited from choosing 28 baby names for their children under the legislation; Uyghurs under the age of 18 are not able to enter mosques to pray or take part in religious activity (Long, 2014).

Also, by this regulation, religious sites are monitored as well as religious ceremonies, such as Ramadhan practices becoming more restricted nowadays. Mosques are now highly regulated and supervised under the guise of a "Mosque Rectification Campaign" over the last half of 2016 (Long, 2014). These forms of oppression are figuring a multidimensional threat to the existence of Uyghur Ethnic identity.

Not only constitute in the context religiousity and cultural banned, each dimension of Uyghur society seems to be 
banned by the authority. In the field of Education, for example, the Chinese government limits educational curricula that teach native language and culture to Uyghurs (Amelia, 2015). In the detention camps, prisoners are forced to study, sing praises to the Chinese Communist Party, and memorize rules that applied particularly to Turkish Muslims. The detainees will not be released before being confirmed as loyal Chinese citizens.

Those who are outside experienced none the better. They were asked to attend a routine political indoctrination meetings. A number of testimonies from Uyghur revealed that in the process of indoctrination of communism Education were obviously intended (Meixler, 2018; Turkel, 2018, UHRP : 2017, Schmitz, 2018). A number of reports also explained that torture, kinda like being electrocuted, beaten and various other forms of violence awaits those who disobey (Meixler,2018).

Responding to this, Adrian Zen from the European School of Culture and Theology the dynamics over China's Policy towards Xinjiang's Uyghurstated that using the term "Pacification", referring to the contemporary situation in Xinjiang is currently the most intense form of state violence against its people. He Wrote :
"China's pacification drive in Xinjiang is, more than likely, the country's most intense campaign of coercive social re-engineering since the end of the Cultural Revolution,..."The state's proclaimed 'war on terror' in the region is increasingly turning into a war on religion, ethnic languages and other expressions of ethnic identity," (Zen, 2018).

The government pleaded their action as a rational choice by considering the history of Xinjiang uprising insurgency by the Uyghurs, which is already occurred even since the Qing Dynasty ruled (Dillon, 2014; Tschantret, 2016). And by the times goes by, the insurgency strategies of Uyghur freedom movement appears to evolve closer to the terrorism characteristic.

Although in the 1997 bombing case, the Turkish-based Organization for East Turkistan Freedom claimed to be a responsible party, the tension has given the Chinese government, measures to declare the Uyghur people as a dangerous group, reflecting on the understanding that Uyghurs had psychological and ethnic, racial, religious and culture bounding with Turkish people.

This radicalist claim on Uyghur has begun to investigated since 1998. It becomes intensely campaigned by China after the events of 11 September 2001 
(CERD,2018;Human Right Watch, 2018).

Seems that, his labelling has been being used as a justifier of Tiongkok repressive policies which has threaten the cultural and religious identity of the Uyghur community.

\section{Xinjiang's Natural Resources;}

\section{Framing of Endogenous Economic}

\section{Growth}

Studies by experts on the Xinjiang conflict, dominantly argues the conflict based on the humanitarianism, human security, human rights violations perspectives. But deliberating the internal conflict between state and its own civiliianz over development process, geopolitical and geoeconomic studies are hardly to ignore. A popular adage states that geography without politics is just a map without meaning. Political geography, in its broadest sense, is an academic study of all variations in resource conflicts and the way in which they are resolved (Blacksell, 2006: 1).

Understanding of the elements of space are the fundamental factors into policy making process of a state both internally and internationally oriented (national and foreign policy). This thesis has also been long held by some global geopolitical thinking, for example

Nicholas J. Spyman in his 1938 work :

"In such a world, the geographic area of the territorial base that operates is a temporary armistice called peace. It is the most fundamental conditioning factor in the formulation of national policy because it is the most permanent ...".

A depth understanding, management, and mastery of territory or space in a political perspective has been well known is one of some key indicator of state power. By understanding the full area of sovereignty, a country will formulate a foreign policy strategy. The use of geopolitical and geo-economic analysis to understand China's case against the Uyghurs in Xinjiang is based on some considerations : First, Muslim population in China is not only disseminate in Xinjiang. But in other regions, there is no upheaval of separatism, and in other regions of Muslim populations both indigenous and immigrant from other countries, has not experienced a ban to worship, cultural or other attributes related to their religious identity.

Although religious education for children is officially forbidden by law in China, the Communist Party allows Hui Muslims to have their children educated in Islam and attend mosques; the law is only 
enforced for Uyghurs. After secondary education, China allows Hui students to study with an imam (Alles, et. Al, 2003). China does not enforce the law against children attending mosques on nonUyghurs outside Xinjiang Since the 1980s Islamic private schools which is well known as sino-Arabic school shave been permitted by the Chinese government in Muslim areas. Hui Muslims employed by the state, are allowed to fast during Ramadan (Beech, 2014). The number of Hui going on Hajj is expanding and Hui women are allowed to wear veils, but Uyghur women are discouraged from wearing them. These facts encircling an understanding that the internal Conflict in Xinjiang can not be over simpilified as a conflict occurs between ideology (Islamic vs Communist).

Second, prior to this modern era, Xinjiang has already imprinted into warlord rivalry and exposed to competition by a variety of political formations. The conflict in Xinjiang is latent and if it is compared to other cases of ethnic discrimination and human rights violations in China, which is already existed along with of political civilization in Chinese history (Dillon 2004: 17-18, Millward 2004: 2-4, Dwyer, 2005).
The trace of Xinjiang's primacy has become easier to trace back since the history of the Qing dynasty. This earlier conquest by the Qing dynasty was not economically motivated, but only oriented towards security and building defenses in the northwestern region of China (Millward, 2007; Clarke, 2008).

Historically, under the Qing's rules, the concept of the 'Great Leap West' has shown its intention to integrate Xinjiang through development. It was a Qing clerk in 1820 who called for investment of canals and windbreaks and the migration of Han peasants and Manchu bannermen to Xinjiang (Tyler 2003:202).

But as what commonly ordered in most of imperialist rulings, the qing dynasty ruled Xinjiang with a strict feudalist imprealism which is led the populations from within Xinjiang felt exploited by local officials (Clarke, ibid). This treatment began to provoke anxiety and raising the seeds of resistance from Uyghur people at that time.

In 1884 Xinjiang was officially conceived as a province of China. The reign continuously pursuing full integration of Xinjiang, politically, culturally,economically, and ideologically. The history of this "Sinicization" has begun, since. At the current dynamics, the 
form of this Sinicization has been evolved, in a different rigorous and opressure method.

Third, in several state official statements and documents, Xinjiang is often stated as one of the central areas of "A Modern Silk Road" which has a mutual supportive relations with the Belt Road Initiative (BRI / OBOR) program. In the PRC government perspectives, asserts that Xinjiang has always been an integral part of China, recalls the history that this region was constituted a pivot in the trade routes of the fabled Silk Road, and thus functioned as a "cultural blotter" for different civilizations from the Middle East, Europe, the Indian subcontinent and China proper. As mentioned in PRC's Embassy 2003 White Document, titling "History and Development of Xinjiang" :

"Since the Western Han Dynasty (206 B.C-24 A.D.), Xinjiang has been an inseparable part of the unitary multi-ethnic Chinese nation. The Chinese central governments of all historical periods exercised military and administrative jurisdiction over Xinjiang. (PRC White Paper, 2003)."

Initiated by the Chinese President $\mathrm{Xi}$ Jinping, OBOR objective is to build trade routes between China and the countries in Central Asia, Europe and Indo-Pacific littoral countries. Since the beginning of its initiation in 2013, OBOR has developed 6 corridors of infrastructure to support the goals of China's economic development, where the Central Asian Region countries are one of the development corridors. Fuller and Star (2016), in a report entitled The Xinjiang Problem, argued that Xinjiang, with its geographical position, was scheduled to be a link between China's political economic relations with central Asian countries.

The history of Xinjiang's importance to modern China increased after the 1979 Soviet invasion of Afghanistan, which led to China's perception of being encircled by the Soviets (Clarke, 2011).

The geographical position of Xinjiang, interest leaning perceiveness from the various of external powers encircling it, draws query about what values of potential does Xinjiang posses, invites the interest to the other state? This kind of question, has always logically explained in an economic-political analysis.

Xinjiang has been already costumized as a transit area for energy transportation from the neighbouring Kazakhstan to China proper. Xinjiang itself possesses rich deposits of oil, natural gas, coal and non-ferrous metals, which is 
alluring for exploration. Xinjiang has $40 \%$ of coal reserves, $22 \%$ of petroleum reserve, and $28 \%$ of gas reserve in the country.

Besides that, the coal deposits in Xinjiang are of higher quality compared to deposits in other provinces, as it contains less sulfur, while the oil deposits are more accessible because most of them are located in shallow and middle strata oilreservoir. Oil-gas fields in Xinjiang are concentrated in Karamay, Tarim Basin, and Turfan Basin. They are three of China's major gas-oil fields in the land, and are among the most productive ones (CNPC: 2013). Some speculation stated that the Tarim Basin oil reserves may be as high as 74 billion barrels of oil and 282 trillion cubic feet of gas (Hasan, 2000).

But even though has a lot of potential, it deserves to be noted that Beijing may be overstating Xinjiang's oil potential. China measures oil reserves that are proven, but not necessarily recoverable (Chrostofferson, 1993 in Boehm, 2009). This potential seems to have been studied for a long time by the Chinese government, although before the facts about natural gas potential in Xinjiang were often exposed, the Chinese government has already construct some economic commodity based development program in Xinjiang, considering what this region mainly produce : Oil and Cotton. (Becquelin, 2000).

Xinjiang's economic development has been very impressive since the 1990s. This was driven by the pattern of China's development after the cultural revolution which emphasized that economic development was a way to overcome socio-political problems, including one in Xinjiang But in 2006, there was a slight change in the focus of developing strategic economic commodities ahead of 2007.

Oil exploration in Xinjiang was directed at supporting China's need for natural gas. China 2020 natural gas market demand will be around 350 billion $\mathrm{m} 3$, and 580 billion in 2030 (Swennen, 2017). To meet the demand for gas, the Chinese government nneds to build a gas pipeline construction project, stretching from

Xinjiang to gas producing countries in the Caucasian region, such as Kazakhstan and Kyrgyzstan. As Asian power reports on January 2019 reported that the Chinese National Energy Administration (NEA) has given the green light for a new $4 \mathrm{Mt} /$ year open-pit coal mining project in the Xinjiang autonomous region in northwestern China, which will benefit from a total investment of CNY854m (US\$126m) (Asian Power, 
2019). In 2018, the domestic raw coal production rose by $5.2 \%$ to nearly 3,550 Mt, thus the China's pipeline network must reach 400 billion $\mathrm{m} 3$ /year in 2020 , and 670 billion in 2030. At the end of 2014 the transmission capacity of China's pipeline network stood at 240 billion $\mathrm{m} 3$. (Swennen, 2017).

Xinjiang retains a rich abundance of natural resources, including oil, coal, and natural gas, and is also critically located, bordering much of Central Asia (Hayes and Clarke,2016 in Steinhauer, 2017). With Chinese direct investments in Central Asia reaching $\$ 250$ billion (USD) in 2012 , the country is seeking to strengthen these ties and its presence in the region through further development of oil and gas pipelines in Xinjiang to connect China to the region (Tukmadiyeva, 2013; Xinjiang Statistical Bureau, 2014). Since 1993, China has been a net importer of oil (Bovingdon 2010). And as long as China's economy and booming population continue to grow at its current pace, so will its energy consumption-which has resulted in an increasing reliance on Xinjiang (Sheives 2006).

\section{Considering the geographical} position and study of Xinjiang's energy potential, it seems rational and acceptable that China strives to maintain its territory and maintain the well-known security of Xinjiang, which never stops the turmoil by carrying out a hard strike policy. Peter Martin's investigative writing, 2019, on Bloomberg news describes the plans for China's government over Xinjiang, as follows:

"Xinjiang sits at the geographic heart of Xi's signature Belt and Road Initiative. It's a trillion-dollar plan to finance new highways, ports and other modern infrastructure projects in developing countries that will connect them to China's markets. "

The government has spent vast sums of building up cities in Xinjiang to attract companies and fuel growth in the relatively poor region. Thus, concerns about lawlessness in Xinjiang could chill investment. Related to Figure 1, referring to the years when the dynamics of FDI were low or experienced a decline, it was noted that in those years the intensity of riots in the Xinjiang region tended to increase. China's campaign against the Uyghurs is aimed at providing a safe place to live and work for investors in Xinjiang. China has invested so much in this region. For this reason, to gain significant return on investment, however, China must not only have control of the region, but also political and economic stability favorable to investment. Figure 1 Shows The 
Surveilance Economy of Security Investment Realted Value in Xinjiang becomes soaring in each year.

Although overshadowed by radical separatism actions, the size of government spending on security and political education in Xinjiang seems reasonable due to the promising income. Enterprise Singapore, a Singapore-owned Enterprise engaged in Business investment, in 2017 issued data on the potential promising economic value of Xinjiang global trade from year to year and in the future as can be seen in Figure 2.

\section{Figure 1. The Surveilance Economy of} Security Investment Realted Value

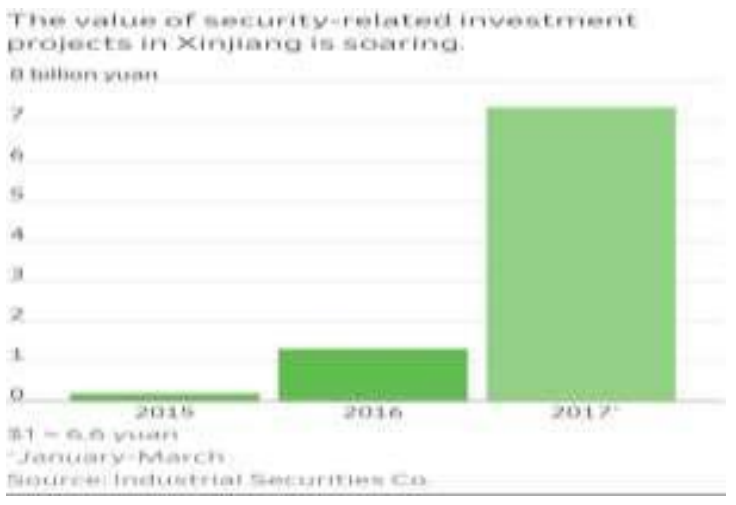

Source : The World Street Journal, 2017.
Figure 2 Trend of Xinjiang Export import Value (2010-2015)

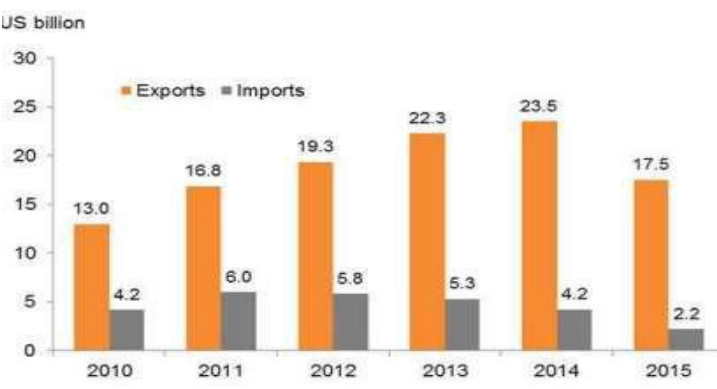

Source : Xinjiang Statistical Yearbook, 2017.

The Xinjiang GDP value overviewed in 2008-2017, also recorded always higher than the national level as sown in Figure 3. To be noted well, along with this upward values of GDP, at the same years the trend of investment and absorption of Foreign Direct Investment has also been growing in Xinjiang. This increasing, cannot be reached suddenly without the impulse of previous development stimulus which was already implemented in the Great Leap West policy (discussed in the previous section) .

Based on the theory of endogenous economic growth, the factors of political economic stability hold a strong influence in determining the smooth economic growth. As a refinement of neo-classical economic theory, endogenous growth theory provides a new theoretical line of thought in analyzing sources of growth. 
This theory reveals that economic growth will be determined by a system that regulates the production process and not from other forces outside the system.

\section{Figure 3. Xinjiang GDP 2008-2017}

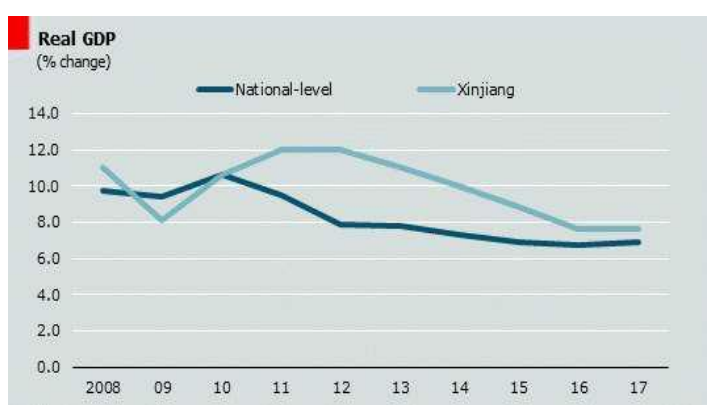

Source : National Bureau of Statistics, The Economist (2018)

The characteristics of endogenous growth models are all factors affecting economic growth. In this context, Drazen (2000) reveals that political economy sees economic performance as a reflection of endogenous political decisions, therefore incorporating political factors as factors that influence growth is very relevant. For Beijing, Xinjiang's stability depends on Uyghur integration within China's large family of nationalities. Integration implies a 'political, cultural, social and economic structuring of a larger state that sees the minorities maintaining their own cultures and identities, but influenced by the majority and not seeking secession' (Clarke 2007b:262).
Dana C. Boehm (2009) in his work, China's Failed War on Terror: Fanning the Flames of Uighur Separatist Violence, overwiewing the Xinjiang conflict in a contemporary geopolitical perspective. Boehm conclusion to

Xinjiang significance is extracted from the histrorical occurrence that the region has shielded China from the Central Asia steppe invasion. And today Xinjiang provides an area of low population where military maneuvers and nuclear testing can be conducted (Harris, 1993).

\section{Xinjiang Inequality of Development as a form of Human Security Issues .}

Despite Xinjiang's potential energy resources, and its large infrastructure development plan which will deplete state expenditure in trillions of yuan, the report by Raymond Lee (2014) shows an inequality tendency in Xinjiang. In his report, it was stated that until 2013, 19 cases of violence by radical groups occurred in the Xinjiang region. This certainly does not count the attacks that occurred in 2015 and 2016. Considering the fact of Xinjiang's strategic position, value of manageable energy resources, contested to this existence of radicalist 
actions, this dynamics simply represents an irony of development.

Xinjiang's economy has grown at an impressive rate (Liu, 2017). Aggregate wages have increased by $470 \%$ (2.3 billion to 10.9 billion). Under the Great Leap West, Xinjiang has been subject to infrastructural projects, investment, and demographic transformation (Tyler 2003; Tian 2004). This modern developmental perspective continues to be choosen as a solution to answer the region's ethnic tensions, even in the aftermath of the 2009 Urumqi riots. Lee's report on ethnic conflict is the irony of the development perspective offered by China. In 2009, Urumqi, the capital of Xinjiang province was notified as the site of the worst social unrest in China since the 1989 Tiananmen Incident (O’Brien 2011).

Amy H.liu's study (2017) plainly stated that using numerical analysis that one of the drivers of this instability is what is explained in the development discourse as Inequality of development. In the case of Xinjiang, even though capital flows have since been planted in the region, but indirectly, the government's decision to mobilize Han's Ethnic gradually but in large numbers is the main source of the tensions that have occurred in Xinjiang. So for the Uyghurs, the great leap is more likely to be a form of colonialism.

Liu's research in 2017, measuring the Xinjiang development program using regression tools, which at a glance macro showed that the Han migrants have profited immensely from the development program, it seems that the Uyghurs have enjoyed the benefits as well. This is measured based on the amount of development, employment opportunities and the disruption in the economic structure. But tracing back more specifically at the demographic composition and ethnic involvement of the Uyghurs, the high absorption of labor or business opportunities is still dominantly felt by ethnic Han's, along with the increasing the Han's transmigrations in Xinjiang. Figure 4 illustrates the changes in ethnic demographic structures between Han and Uyghur. 
Figure 4. Changes in ethnic demographic structures between Han and Uyghur.

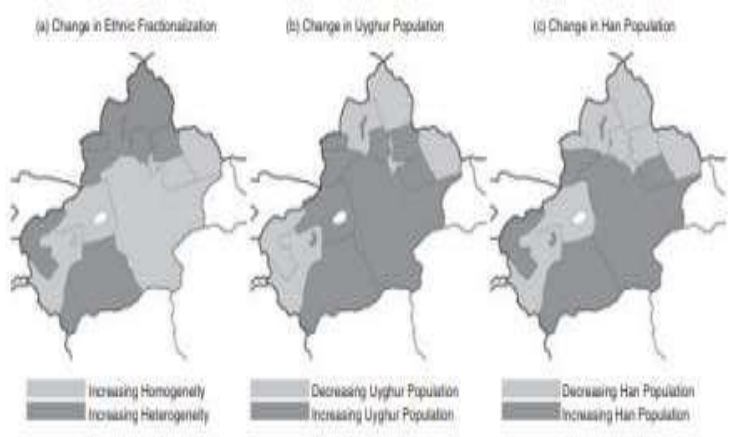

Source : Liu (2017)

At the beginning of China's independence in 1949, the Uyghurs represented over $75 \%$ of the total population; in contrast, the Hans only accounted for $7 \%$. Today, Uyghurs represent only $46 \%$ of the total population.

Conversely, the Hans are now at least $40 \%$ of the total Xinjiang population (Xinjiang Uyghur Autonomous Region Bureau of Statistics 2010). In this situation, China faces development discourse as Development Inequality between Han and Uyghur ethnicity.

Study of Zang (2011) stated that from the aspect of average income, in 2011, Uyghurs earn 892 RMB/year, while Han is earning an average income of 1,141 RMB/year. Also in the context of urban and rural settlement areas are just stark, where, the majority of Hans are concentrated in the more economically developed areas; the Uyghurs and Turkic peoples, in poorer regions (Wiemer 2004). Ethnic profiles are also prevalent in job hiring dynamics (Zang 2011).

While the urban-rural income gap in Xinjiang is used to mirror that of the national average, today it is 30\% higher (Cao 2010). Similar inequality portrayals were written by CERD-OHCR in the 2018 investigation report, which includes the employment sector in companies, education, occupation, to wages :

“ Rapidly developing industries including the energy service sector, and government positions are dominated by Han Chinese living in the region and Uyghurs are largely excluded from the benefits and employment opportunities on account of ethnicity and language...The Xinjiang Production and Construction Corps (Bīngtuán), a state-controlled organization,

employs upwards of 2.7 million people, though Uyghurs made up only seven percent of its workforce in 2014.... (CERD-OHCR,2018)."

Inequality and discriminative education policies also occurs targeting Uyghurs education and cultural system are widespread. Curriculum for Uyghurs has deemphasized or eliminated teaching on language, culture and religion, and language policies in education continue to 
erode the Uyghur language from a young age (CERD-OHCR,2018). The regional government has now set a target of 2,600,000 students in East Turkestan by 2020 which constitutes nearly all nonChinese students. To facilitate this language program, there has been a substantial influx of Han Chinese teachers incentivized to relocate to the region to work, while Uyghur teachers are fired or are not able to find jobs in education.

In the field of security studies, the situation faced by the Uyghurs in Xinjiang, can be seen as a symptom "Human Insecurity" which is driven by uneven distribution in the vortex of developmentalization. Human security as an emerging paradigm for understanding global vulnerabilities whose proponents challenge the traditional notion of national security by arguing that the proper referent for security should be at the human rather than national level.

\section{At 1994 Human Development} Report by UNDP, define this concept of human security should be expanded to include threats in seven areas: Economy, Food, Health, Environmental, Personal, Community and Politcal Security that every Independence state should accommodate to their citizen. This definition has been broaden from earlier concept from military aspects into non military aspects, particularly the promotion of economic and justice of development (Mc Namara, 1968 in Sam, 2002).

Another inherent fundamental aspects in the conceptualization of human security is, Freedom Principles, which consists of Freedom From Fear and Freddom from Want. While the facts in Xinjiang, the development policies along with the Detention programs run by China's Government thorughky violated this principles. The study of development relations with the creation of Human Security correlates each other.

"Freedom from fear" in Tadjbakhsh and Chenoy (2006) argument, means human development and human security are inextricably linked since progress in each one, enhances the chances of progress in another while failure in one increases risk of failure of another. Adopted from Tadjbakhsh, the correlation between Human security and Development bridged by five variables : Values; Orientation,Time Frame, General Objectives and Policy Goals. Description of the values of those 5 bridging variable shown in Table 1. 
Table 1. Description of 5 bridging variables between Human Security and Development.

\begin{tabular}{|c|c|c|}
\hline Variable & Human Development & Human Security \\
\hline Values & Well-being. & $\begin{array}{l}\text { Security, } \\
\text { stability, } \\
\text { sustainability of } \\
\text { development } \\
\text { gains }\end{array}$ \\
\hline Orientation & $\begin{array}{l}\text { Moves forward, is progressive } \\
\text { and aggregate: "Together we } \\
\text { rise" }\end{array}$ & $\begin{array}{l}\text { Looks at who } \\
\text { was left behind } \\
\text { at the individual } \\
\text { level: }\end{array}$ \\
\hline $\begin{array}{l}\text { Time } \\
\text { Frame }\end{array}$ & Long term & $\begin{array}{l}\text { short-term } \\
\text { measures to deal } \\
\text { with risks with } \\
\text { long term } \\
\text { prevention } \\
\text { efforts. }\end{array}$ \\
\hline $\begin{array}{l}\text { General } \\
\text { objectives }\end{array}$ & $\begin{array}{l}\text { Growth with equity. } \\
\text { Expanding the choices and } \\
\text { opportunities of people to lead } \\
\text { lives they value. }\end{array}$ & $\begin{array}{l}\text { Identification of } \\
\text { risks, prevention } \\
\text { to avoid them } \\
\text { through dealing } \\
\text { with root causes, } \\
\text { preparation to } \\
\text { mitigate them,. }\end{array}$ \\
\hline $\begin{array}{l}\text { Policy } \\
\text { goals }\end{array}$ & $\begin{array}{l}\text { Empowerment, sustainability, } \\
\text { equity and productivity. }\end{array}$ & $\begin{array}{l}\text { Protection and } \\
\text { promotion of } \\
\text { human survival } \\
\text { (freedom from } \\
\text { fear), daily life } \\
\text { (freedom from } \\
\text { want), and the } \\
\text { avoidance of } \\
\text { indignities (life } \\
\text { of dignity) }\end{array}$ \\
\hline
\end{tabular}

Source : Adpted from Tadjbakshsh and Chenoy (2006)

The values outlined in the relations of Human Security and Development are based on the facts, is a rarity in Xinjiang. This is could easily being understood as the main stimulant of small resistance from the Uyghur ethnic group, as indigenous people who embrace injustice in their own country. This situation by Jessica Stern, described in the term "simplify life", as the main factor that can trigger the attachment of the population of a nation into a group or form a separate group with the same flow of thought, the same suffering to find collective strength to find a life that is "easy "Rather than looking for a way out individually. As Stern said :

"People join religious terrorist groups partly to transform themselves and to simplify life. They start out feeling humiliated, enraged that they are viewed by some 'others second class.... The weak become strong.. " (Stern, 2003, 2004).

People join terrorism groups to vent their fatigue in facing various forms of social system injustice and by gathering, they will feel strong and feel able to fight. The victim role aswell as longstanding historical injustices and grievances may be constructed to serve as justifications for terrorism (bjorgo, 2005).

For example, perhaps, the most rigorous formalization of group conflict (and state capacity more broadly) that integrates many of the causal variables from existing studies, such as redistributive institutions (that may, for example, stem from differences in ethnic fragmentation and/or political institutions), taxation, and unearned income omits 
international factors completely (Besley and Persson 2009, 2010, 2011).

The high prevalence of deprivation and the degrading of human rights are the main drivers that motivate someone to gather or join a terror group. Data from the UNDP Human Development Index presents data on the correlation between human rights violations against the involvement of individuals into a terrorism group. Figure 5 shows that Poverty has a low correlation to terrorism or radicalism.

Eventhough,, unresolved poverty could drive unemployment and the injustice feeling of the society. The people will become more susceptible to the false promises of those who favor terrorists methods to bring about social and political change (Schmid in Bjorgo, 2005). Contrary to poverty, violations of human rights are so high in correlation with one's involvement in terrorism groups as can be seen in figure 6 . The better the handling of human rights of a social system, the lower the prevalence of involvement of social entities in radical activities.

The logic between inequality of development and the proliferation of radical resistance, can clearly illustrate the dynamic conflict in Xinjiang. Two large narratives appear to emerge. The narrative or perspective of the Uyghur community, violence is a daily dynamic that must be faced, and complicates their living space. in their perspective, they become indigenous people who are marginalized in the land by the capital flows and development policies. Violence against Uyghurs in Xinjiang has also transformed from non-physical, where they experience multidimensional discrimination, into physical violence which contitutes the key elements of radicalism raising.

\section{Figure 5. Correlation Between Poverty} and Terrorism by UNDP

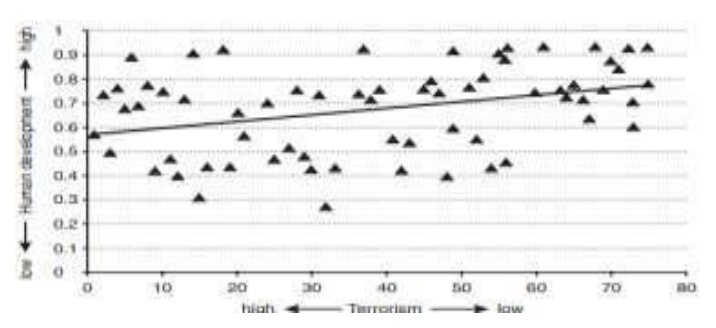

Source : UNDP, (2016).

\section{Figure 6. Correlation between preservation of Human Right and Terrorism}

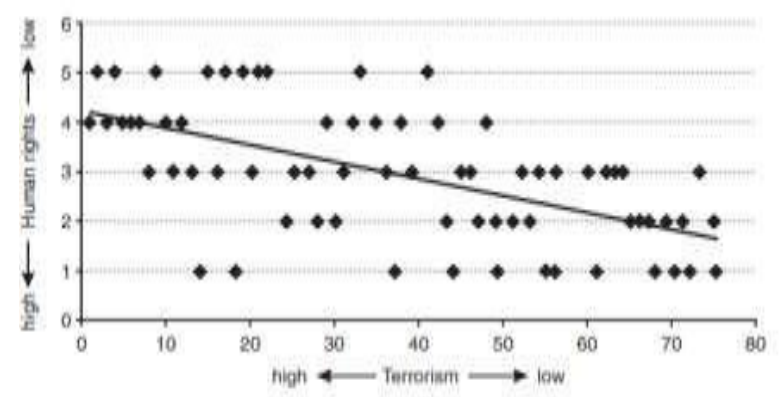

Source : UNDP (2016)

The second narrative, the Chinese government considers that integrating 
Xinjiang is to maintain territorial integrity and China's sovereignty. On the other hand, the geo-economic aspect of Xinjiang's important position, is the main element determining the success/ smoothness of China's geo-political megaprojects summarized in the OBOR.

Therefore Xinjiang security is very important to be realized. The existence of radicalism will disrupt all these narratives. So that in the response of the Chinese government, fertile radicalism must be overcome with "discipline" as now reflected in the "Strike Hard" policy contestation.

This article, then construct the logic of all of these narration simply, in the author's arrangement into a conceptual thingking exposed in chart 1 below

Chart 1. The logic of Violence, Development Inequality, Strike Hard

\section{Policy and Xinjiang Conflict.}

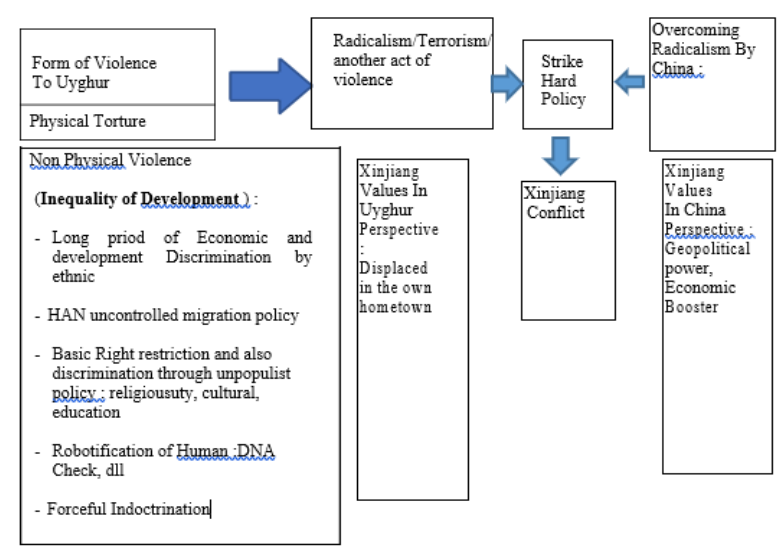

Source : Writers

\section{E. Conclusion}

The realism perspective in international relations considers that the state is a rational actor who has the nature to maintain his power and (if he can) expand. Hardline Policy and China's development efforts in the case of Xinjiang, can be seen as a form of defense against sovereignty. Records of radicalism for years can be seen as a rational reason for China to take such actions, and in the view of the government physical development and stimulus of fixed capital flows must be done to achieve equity so that radicalism or separatism will slowly disappear.

But there is a gap in that thought. Since tracing the history of excesses from state policies in Xinjiang, development inequality appear to be real. The flow of capital and infrastructure development cannot always maintain as the primary solution to this problem. Moreover if overcome through coercion and violence "Hard Strike" strategy would turn out worsen.

Because inequality has been going on for so long and touches on the fundamental rights of the Uyghur community, which cultivates the fertility of radicalism / separatism. such initiatives need to be taken with local consideration. 
This is especially urgent when the change widen extant levels of economic inequality and when the income differentials mirror ethnic cleavages (Horowitz 1985). Because for Uyghurs, the issue of ethnical discrimination is paramount. Especially driven by HAN migration to Xinjiang. And once radicalism has been embraced, very few return to pacifism (Stern,2004). For this reason, China's goal should not be to convert the violent; rather its goal should be to compete with the terrorists for the hearts and minds of the broader population, upon whom the radicalist rely for support.

\section{REFERENCES}

America's Climate Choices: Panel on Advancing the Science of Climate Change, National Research Council (2010). "" Chapter 16. National and Human Security".". Advancing the Science of Climate Change. Washington, DC: The National AcademiesPress.p. 389. Retrieved 1 6 February 2019.

Alles, Elisabeth. Et al. 2003. Chinese Islam :Unity and Fragmentation. Religion, State \& Society Volume 31 No 1. P.7-35
Amelia, F. 2013. Etnisitas Dan Politik Luar Negeri: Respon Turki Terhadap Penindasan Etnis Uyghur Di XinjiagG. Journal Analisis Hubungan Internasional, Universitas Airlangga. Vol.2/No.3. P. 295-317

Becquelin, N. (2000). Xinjiang in the Nineties. No.44, July. The China Journal. P. 65-90

Beech, Hannah. 2014. If China Is AntiIslam, Why Are These Chinese Muslims Enjoying a Faith Revival. Time News Report. URL : http://time.com/3099950/china-muslimhui-xinjiang-uighur-islam/. Last Access 14 February $14^{\text {th }} 2019$ Besley, Timothy and Persson, Torsten. 2009. The origins of state capacity: property rights, taxation and politics. American economic review, 99 (4). pp. 1218-1244.

Bjorgo, Torre. 2005. Root Causes of Terroris : Myths, reality and ways forward. New York : Routledge.

Blacksell, Mark(2006), Political Geography, Routledge: London Boehm, D Carver. 2009. China's Failed War on Terror: Fanning the Flames of Uighur Separatist Violence. Volume 2 Berkeley J. Middle E. \& 
Islamic Law. Volume 2 Article 3.

Berkeley : UC press. P. 70-75

Bovingdon, Gardner. 2010. The Uyghurs:

Strangers in Their Own Land. New

York: Columbia University Press.

Cao, Huhua. 2010. Urban-Rural Income

Disparity and Urbanization: What Is the Role of Spatial Distribution of Ethnic Groups? A Case Study of Xinjiang Uyghur Autonomous Region in Western China. Regional Studies 44 (8): 965-82.

CERD Report. 2018. Parallel Submission to the Committee on the Elimination of Racial Discrimination (CERD) for the People's Republic of China (PRC) 96th Session, 6-30 August 2018. World Uyghur Congress [Online]-

URL

https://tbinternet.ohchr.org/Treaties/ CERD/Shared\%20Documents/CHN IINT_CER

D_NGO_CHN_31745_E.pdf.

Clarke, Michael. 2007. China's "war on terror" in xinjiang: human security and the causes of violent uighur separatism. Regional Outlook Paper, No. 11, 2007 Griffith Asia Institute.

Clarke, Michael. 2008. China's Integration of Xinjiang With Central Asia, Securing "A Silk
Road" To Great Power StatuS?.

China and Eurasia Forum Quarterly, Volume 6, No2. Central Asia

Caucasus Institue \& Silk Road Program.

Clarke, Michael, 2010. China, Xinjiang and The Internasionalization Of The Uyghur Issue. Global Change Peace \& Security Volume 22. Issue 2. Griffith Asia Intitute. P. 213-229.

Clarke, Michael E. 2011. Xinjiang and China's Rise in Central Asia - A History. Retrieved 10 March 2014. P. 90-111

CNPC. 2014. Location Of Oil Reserve In China [Zhongguo Shiyou Fenbu]. URL

http://www.cnpc.com.cn/News/zzx $\mathrm{w} / \mathrm{sybk} / \mathrm{syzs} / \mathrm{sysh} / 201310 / 20131011$ C191.sht1?COLLCC $=7320640 \& \mathrm{C}$

OLLCC $=2517866373 \&$. Last Acces February, $15^{\text {th }} 2019$.

Dillon, Michael. 1997. Ethnic, Religious and Political Conflict on China's Northwestern Borders : The Background to The Violence in Xinjiang. IBRU Boundary and Security Bulletin. Volume 5, Number 1, (Spring): 80-86

Drazen, A. (2000), Political Economy in Macroeconomics. Princeton: Princeton University Press 
Dwyer, Arienne. 2005. Policy Studies :

The Xinjiang Conflict " Uyghur

Identity, Language Policy, and

Political Discourse. Washington : East West Center.

Graham, E. Fuller, and Frederick Star.

2016. The Xinjiang Problem.

Baltimore : Central Asia-Caucasus

Institute. Paul H. Nitze School of

Advanced International Studies.

Harris, Lilian Craig. 1993. Xinjiang,

Central Asia and the Implications

for China's Policy in the Islamic

World. The China Quarterly, Vol.

133. Cambridge : Cambridge

University Press

Hasan, Nader. 2000. China's Forgotten

Dissenters: The Long Fuse of

Xinjiang, Harvard International

Review. Fall 2000, 22 (3) 41.

Hughes, Roland. 2018. China Uighurs: All you need to know on Muslim 'crackdown'. BBC Report November $8^{\text {th }}$ 2018. URL : https://www.bbc.com/news/worldasia-china-45474279. Last Acces : February $12^{\text {th }} 2019$

Human Right Watch Report. 2018. Eradicating Ideological Virus.

Chin's Campaign of Repression Against Xinjiang's Mulims. September 2018. URL : https://www.hrw.org/sites/default/fil es/report_pdf/china0918_web.pdf. Last Acces $17^{\text {th }}$ February 2019 Lee, R. 2014. Unrest in Xinjiang, Uyghur Province in China Report. Aljazeera Center for Studies. URL :http://studies.aljazeera.net/mritems /Documents/2014/2/20/2014220921 643580Province\%20in\%20China.p df. Last Acces : February, $16^{\text {th }}$ 2019.

Liu, Ami et Kevin Peters. 2017. The Hanification of Xinjiang, China: The Economic Effects of the Great Leap West. Studies in Ethnicity and Nationalism, Vol.17 No.2. Texas : University of Texas Press. P. 265280

Long, Q. 2014. China Clamps Down on 'Underage Religion' Among Muslim Uyghurs. Radio Free Asia Uyghur Service. URL :

https://www.rfa.org/english/news/uy ghur/underage10302014120731.htm 1. Last Acces date February $13^{\text {th }}$ 2019.

Meixler, E. 2018. 'I Begged Them to Kill Me.' Uighur Woman Tells Congress of Torture in Chinese Internment Camps. Times, News Report November $30^{\text {th }}$ 2018. URL : http://time.com/5467628/china- 
uighur-congress-torture/. Last

Acces February 21th 2019.

Millward, James A, 2007. Eurasian Crossroads: A History of Xinjiang.

New York: Columbia UP. Print.

Strategy in Central Asia. Griffith Asia Institute.

URL:

http://www.gu.edu.au/centre/asiains titute/pdf/ChinaPost911.pdf.

O'Brien, David. 2011. 'The Mountains Are High and the Emperor Is Far Away: An Examination of Ethnic Violence in Xinjiang'. International Journal of China Studies 2 (2): 389405.

PRC Embassy. 2003. History and development of Xinjiang. White Paper.

Sam, J. Busumtwi. 2002. Development and Human Security : Whose Security, and From What?. International Journal Vol. 57, No. 2 (Spring, 2002). Sage Publication. pp. 253272/

Schmitz, Rob. 2018. Ex- Detainee Describes Torture in China's Xinjiang Re-Education Camp. News Report on NPR november $13^{\text {th }} 2018$. URL :https://www.npr.org/2018/11/13/6 $\underline{66287509 / \text { ex-detainee-describes- }}$ torture-in-chinas xinjiang-re- education-camp. Last Acces on February 21th 2019.

Sheives, Kevin. 2006. 'China Turns West: Beijing's Contemporary Strategy Towards Central Asia'. Pacific Affairs 79 (2): 205-24.

Steinhauer, I. 2017. International Social Support and Intervention : The Uyghur Movement-Xinjiang Province, China. Undergraduate Honors Thesis. University of Colorado Boulder.

Stern. J. 2004. Holy Avengers. News Article on Financial Times, 12 June 2014. [online]https://www.belfercenter.org/public ation/holy-avengers.

Stern, J. 2003. Terror in the Name of God: Why Religious Militants Kill. New York: HarperCollins. Swennen. Rudy (ed.). 2017. China Gas Development Strategis Advances in Oil and Gas Exploration \&Production. Cham : Springer Nature.

Tadjbakhsh \& Chenoy, Human Security: Concepts and implications, London: Routledge, 2006

Tschantret, Joshua. 2016. Repression, opportunity, and innovation: The evolution of terrorism in Xinjiang, 
China. Journal Center Asian

Survey. Volume 30 Nomor 4. P. 569-588.

Tukmadiyeva, Malika. 2013. quarterly Journal, Summer. [online]http://dss.gov.cn/Article_Print.asp? ArticleID=244017. P.87 -107.

Turkel, Nury. 2018. Hearing China's Repression And Internment of Uyghurs: U.S. Policy Responses. Uyghur Human Rights Project House Committee on Foreign Affair Subcommittee on Asia and the Pacific. URL : https://doc.house.gov/meetings/FA/ FA05/20180926/108718/HHRG-

115-FA05 Wstate TurkelN-
20180926.PDF. Last Acces February $10^{\text {th }} 2019$.

Tian, Qunjian. 2004. 'China Develops Its West: Motivation, Strategy and Prospect'. Journal of Contemporary China 13 (41): 611-36.

Tyler, Christian. 2003. Wild West China: The Taming of Xinjiang. New Brunswick, NJ: Rutgers University Press.

UHRP Report. 2018. The Mass Internment of Uyghurs :We Want To Be Respected as Humans, Is It Too Much To Ask?. URL : https://docs.uhrp.org/pdf/MassDeten
tion_of_Uyghurs.pdf. Last Acces on February $7^{\text {th }} 2019$.

Weiwen,Y. 2016. The natural resource curse in Xinjiang. CEU Political Science Journal Volume 10 (1) . January 2016. Budapest : CEU Press. P. 122-140

Wiemer, Calla. 2004. The Economy of Xinjiang'. In Xinjiang: China's

Muslim Borderland, ed. S. Frederick Starr. Armonk, NY: M.E. Sharpe.

Xinjiang Statistical Yearbook,2015

Zang, Xiaowei. 2011. Uyghur-Han Earnings Differentials in Ürümchi. The China Journal 65: 141-55.

Zens, Adrian. 2018. New Evidence for China's Political Re-Education Champaign in Xinjiang. China Brief, Vol. 18 No 10.

Zhao, Huasheng, (ed.). 2007. Central Asia in China's Diplomacy : The View from Washington, Moscow and Beijing. New York : Routled 